\title{
Cloning and Expression in Escherichia coli of Proteus vulgaris Genes for 16S Ribosomal RNA
}

\author{
By HEINO NIEBEL, MATTHIAS DORSCH AND ERKO STACKEBRANDT* \\ Institut für Allgemeine Mikrobiologie, Christian-Albrechts-Universität, Olshausenstr. 40, \\ D-2300 Kiel, Federal Republic of Germany
}

(Received 23 December 1986; revised 13 March 1987)

\begin{abstract}
In contrast to the established systems of plasmid-coded homologous ribosomal DNA (rDNA) cistrons in Escherichia coli little is known about the fate of heterologous rRNA. In order to study expression of foreign rDNA, rRNA cistrons from Proteus vulgaris were cloned in phage vector Charon 35, subcloned in pBR322 and transformed in E. coli. The inserts of two clones (pPM2 and pPM14) were characterized by restriction analysis and Southern hybridization. Each of them harboured a complete rrn cistron. The location of rRNA genes of clone pPM2 was also verified by R-loop analysis. The $5^{\prime}$ flanking region of the $16 \mathrm{~S} \mathrm{rRNA}$ of pPM 2 was sequenced and compared to the $E$. coli counterparts. High-level homologies exist in the functional parts of this region, e.g. promoters, box A and RNAase III recognition site. The copy number of pPM2 and pPM14 was estimated to be 8 and 10, respectively. Clones showed a markedly reduced growth rate (generation time about 57 to $70 \mathrm{~min}$ ) as compared to the non-transformed cells (generation time $40 \mathrm{~min}$ ). rDNA cistrons of $P$. vulgaris were properly expressed and the transcripts are processed as demonstrated by the presence of $16 \mathrm{~S}$ rRNA from $P$. vulgaris in both ribosomes and $30 \mathrm{~S}$ ribosomal subunits isolated from the transformed $E$. coli cells. The fraction of heterologous rRNA in ribosomes was about $25 \%$.
\end{abstract}

\section{INTRODUCTION}

All previous studies investigating the function of ribosomal RNA during translation and the role these molecules play in the regulation of ribosomal proteins have been performed in Escherichia coli using plasmids carrying homologous rRNA cistrons with either unaltered (Ikemura \& Nomura, 1977) or in vitro-altered primary structures (Gourse et al., 1982; Stark et al., 1982; Skinner et al., 1985; Jemiolo et al., 1985; Meier et al., 1986). In most cases plasmid pKK 3535 (Brosius et al., $1981 a, b$ ), carrying the $E$. coli $r r n B$ cistron, has been used, since with this system expression and incorporation of $16 \mathrm{~S}$ and $23 \mathrm{~S}$ rRNA in ribosomes has been demonstrated (Gourse et al., 1982). Compared to the wild-type strain, the presence of additional copies of plasmid-coded unaltered or mutated rDNA genes resulted in a more or less dramatic reduction of doubling time.

Translation experiments, using $E$. coli r-proteins and 16S rRNA from different sources, have shown (Nomura et al., 1968) the high degree of conservatism of ribosomal components, allowing their in vitro replacement even over large genealogical distances. However, a successful in vivo expression of a plasmid-coded $E$. coli 5S rRNA gene in Pseudomonas putida was only reported recently (Hartmann et al., 1985).

In order to obtain a better insight into the fate of heterologous 16S rRNA we cloned Proteus vulgaris complete rDNA cistrons in $E$. coli. Recovery of $P$. vulgaris $16 \mathrm{~S}$ rRNA from $E$. coli ribosomes is a prerequisite for the identification of rRNA expressed from a successfully transformed and functional heterologous $r r$ cistron in the $E$. coli genome. 


\section{METHODS}

Cloning of ribosomal DNA. Chromosomal DNA from Proteus vulgaris IFAM 1731 (IFAM = Institut für Allgemeine Mikrobiologie, Universität Kiel) was digested with BamHI. Since fragments of size 9-20 kb are suitable for cloning in substitution phage vector Charon 35 (Loenen \& Blattner, 1983) fragments larger than $8 \mathrm{~kb}$ were enriched by ultracentrifugation $(10-30 \%$, w/v, sucrose). Respective fractions were pooled and precipitated with ethanol. DNA from Charon 35 was digested with BamHI and the cos-sites of the arms were ligated according to Maniatis et al. (1982). Arms were separated from stuffer fragments by $10-30 \%$ (w/v) sucrose gradient ultracentrifugation. Arms and restriction fragments from $P$. vulgaris were mixed under conditions which favour the generation of large concatamers. After ligation DNA was in vitro packaged (in vitro packaging extracts were a gift from K. Apel, Kiel) and plated on E. coli K802 or K803. Phage clones harbouring ribosomal cistrons were identified by plaque hybridization (Maniatis et al., 1982) with $5^{\prime}-\gamma^{3}{ }^{32} \mathrm{P}$-labelled 16S rRNA from $P$. vulgaris on Hybond N (Amersham/Buchler) (Reed \& Mann, 1985). [ $\left.\gamma^{32} \mathrm{P}\right]$ ATP was from NEN. DNA from single clones was extracted from phage minipreparations (Maniatis et al., 1982) and digested with BamHI. Fragments were separated on a $0.7 \%(\mathrm{w} / \mathrm{v} /)$ agarose gel. Insert DNA was eluted with NA-45 DEAE paper (Schleicher and Schuell) and subcloned in plasmid pBR322. Competent cells of E. coli HB101 were transformed as described (Mandel \& Higa, 1970; Dagert \& Ehrlich, 1979). Bacterial clones containing 16S rDNA from P. vulgaris were identified either by colony hybridization (Grunstein \& Hogness, 1975) or by Southern hybridization (Southern, 1975) of plasmid minipreparations (Birnboim \& Doly, 1979). Detailed restriction and gene maps of two different recombinant plasmids (pPM2 and pPM14) were obtained by digesting the inserts with various restriction enzymes, followed by Southern hybridization with $\gamma^{32} \mathrm{P}$-labelled $16 \mathrm{~S}$ and $23 \mathrm{~S}$ rRNA from $P$. mirabilis. Maps were verified by Bal31 analysis of selected fragments (Perbal, 1984). Restriction enzymes were purchased from Boehringer Mannheim.

Expression of rDNA. Expression of heterologous rDNA in E. coli was determined by 16S rRNA fingerprint analysis. Cells were lysed and debris was pelleted $(45000 \mathrm{~g})$ in a Sorvall centrifuge. The supernatant was centrifuged (44000 r.p.m., 2 h, rotor type TFT 65.38 ) in a Contron ultracentrifuge to pellet ribosomes. These were phenolextracted twice and the rRNAs precipitated with ethanol. Alternatively $16 \mathrm{~S}$ rRNA was extracted from the small subunit of ribosomes (Traub et al., 1971; Zablen \& Woese, 1975). The nucleic acids were separated by preparative $2.8 \%(\mathrm{w} / \mathrm{v})$ PAGE. 16S rRNA was electroeluted using the Biotrap apparatus (Schleicher and Schuell) as indicated by the manufacturer, extracted twice with phenol and precipitated with ethanol. RNAase T1 digestion, 5'labelling of oligonucleotides with $\left[\gamma^{-32} \mathrm{P}\right] \mathrm{ATP}$ and polynucleotide kinase, and the generation of a fingerprint were done as described previously (Stackebrandt et al., 1985).

The fingerprint obtained was compared with those of pure 16S rRNA of E. coli HB101 and P. vulgaris. $P$. vulgaris-specific oligonucleotides were analysed further by partial alkaline hydrolysis and two-dimensional mobility shift analysis (Stackebrandt et al., 1985). To estimate the ratio of homologous and heterologous oligonucleotides in the 'mixed' fingerprint, the corresponding material from selected spots was isolated from the thin-layer plate (Stackebrandt $e t$ al., 1985) and the radioactivity determined in a scintillation counter (Philips).

Growth measurements were performed by transferring similar amounts of inocula of clones harbouring pPM2 and pPM14, E. coli HB101, E. coli (pKK3535) (Brosius et al., 1981 b) and E. coli (pBR322) in LB medium (Maniatis et al., 1982) supplemented with $80 \mu \mathrm{g}$ ampicillin $\mathrm{ml}^{-1}$ (except for HB101). Cells were shaken (250 r.p.m. at $37^{\circ} \mathrm{C}$ ) and cell density measured at $578 \mathrm{~nm}$.

Sequencing of promoter region. The nucleotide sequence of the promoter region was determined by subcioning the $1.2 \mathrm{~kb}$ HindIII and the $1.8 \mathrm{~kb}$ BamHI-BglII fragment from pPM2 in phage M13mp8 (Messing \& Vieira, 1982). The sequencing reaction was carried out according to Sanger $e t$ al. (1977) using the universal primer (Boehringer Mannheim) and a synthetic primer approximately $250 \mathrm{bp}$ upstream from the $5^{\prime}$-terminus of the $16 \mathrm{~S}$ rRNA gene. Both $\left[\alpha^{-32}\right.$ P]ATP and dATP $\alpha^{35}$ S (NEN) were used as radionucleotides. Sequencing analysis was carried out on $6 \%(w / v)$ PAGE gels using an LKB sequencing apparatus.

Determination of plasmid copy number. This was done by separating $5 \mu \mathrm{g}$ BamHI-digested total DNA of $E$. coli harbouring plasmid pPM2 or pPM14 on a $0.7 \%(w / v)$ agarose gel, adjacent to samples containing copies of Bam HI-digested plasmid DNA ranging from an amount equivalent to the total amount of chromosomal DNA to 256 times this amount. Plasmids were purified from RNA by treatment with RNAase T1 (Calbiochem-Behring) and RNAase A (Boehringer Mannheim), followed by centrifugation through $1 \mathrm{M}-\mathrm{NaCl}$ (Maniatis et al., 1982). Each sample was adjusted to $5 \mu \mathrm{g}$ by adding the appropriate amount of BamHI-digested salmon sperm DNA. After separation, fragments were blotted to Hybond $\mathrm{N}$. The membrane was hybridized with $5^{\prime}-32 \mathrm{P}$-labelled $16 \mathrm{~S}$ rRNA from $P$. vulgaris and exposed to an X-ray film. Hybridization conditions were stringent to minimize crosshybridization with $E$. coli chromosomal rDNA cistrons. The signal strength of the plasmid bands of the clones was compared to those of the purified plasmids ( $K$. Apel, personal communication).

$R$-loop analysis. DNA of isolated BamHI insert of pPM2 was crosslinked by treatment with Trioxsalen (Sigma), followed by UV-irradiation. After hybridization with $16 \mathrm{~S}$ and $23 \mathrm{~S}$ rRNAs, the DNA was modified by glyoxal 
(a) $\mathrm{pPM} 2$

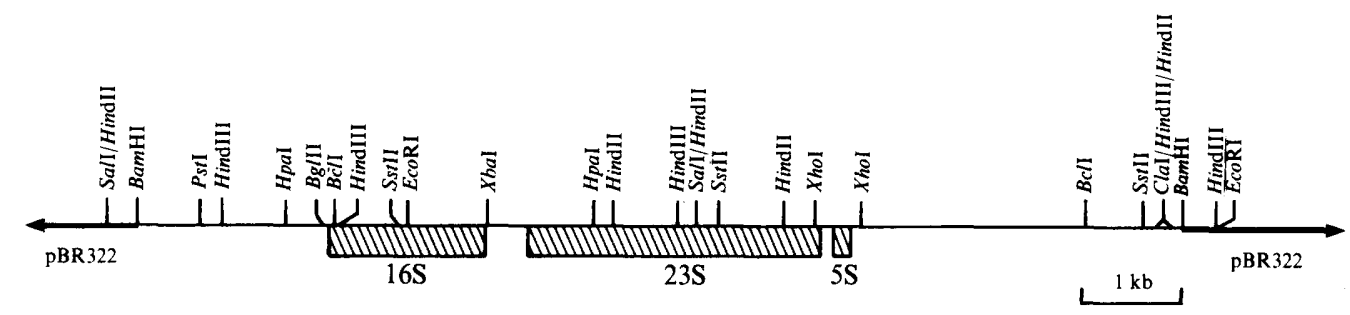

(b) pPM14

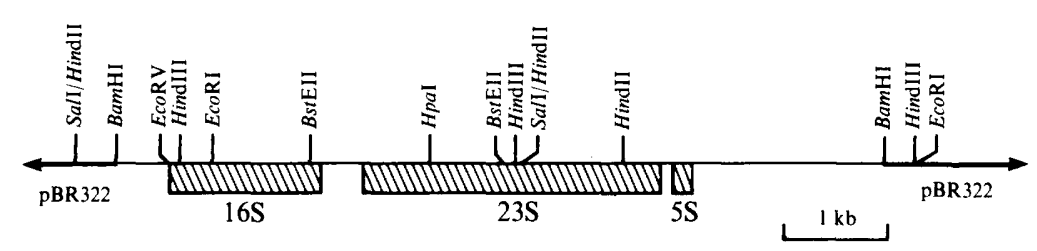

Fig. 1. Restriction maps of the cloned Proteus vulgaris rrn cistrons. The location of the 5S rRNA gene was deduced from the position of the corresponding gene in the $E$. coli cistrons. (a) Plasmid pPM2, $15 \mathrm{~kb}$. The order of the $3^{\prime}$ terminal restriction sites $C l a \mathrm{I}$, HindIII and HindII could not be resolved. $(b)$ Plasmid pPM14, $12 \mathrm{~kb}$.

(Sigma). The resulting R-loops were spread with cytochrome $c$ and $\mathrm{Pt} / \mathrm{C}$ rotary-shadowed (Cech \& Pardue, 1976; Casey \& Davidson, 1977; Kaback et al., 1979; Woolford \& Rosebash, 1979). Electron microscopy was done with a Philips EM 300; length measurements were done with a Morphomat (Zeiss).

\section{RESULTS AND DISCUSSION}

Proteus vulgaris was chosen as a source for testing the expression of heterologous rDNA in $E$. coli. On the basis of $16 \mathrm{~S}$ rRNA cataloguing, both organisms are members of the gamma subdivision of purple phototrophic bacteria and their non-phototrophic relatives, sharing a moderate degree of relationship $\left(S_{\mathrm{AB}}\right.$ value $\left.0 \cdot 68\right)$.

\section{Cloning and sequence comparison}

Three different rDNA cistrons from $P$. vulgaris were cloned in phage vector Charon 35 . The sizes of the inserts were about $7.5,10.5$ and $13.5 \mathrm{~kb}$. The two smaller inserts were subcloned in plasmid vector pBR322, but attempts to subclone the $13.5 \mathrm{~kb}$ insert failed, possibly due to the fragment size (Perbal, 1984). Fig. 1 presents gene and restriction maps of the two recombinant plasmids pPM2 and pPM14.

The locations of the rRNA genes within the insert of pPM2 were verified by R-loop analysis (Fig. 2). The total length of the insert $(10.5 \mathrm{~kb})$ as determined by restriction analysis is in accordance with the dimensions determined after electron microscopy.

Both recombinant plasmids possess a complete rDNA cistron including promoters and terminators, a prerequisite for proper transcription and processing in the host. In the case of pPM14 this was not obvious from the restriction map but could later be demonstrated by recovery of pPM14-coded $16 \mathrm{~S}$ rRNA in $E$. coli ribosomes.

The $5^{\prime}$ flanking region of $P$. vulgaris rRNA clone pPM2 (Fig. 3) contains putative promoters, a discriminator region, a box A region responsible for antitermination function (Morgan, 1986) and the $5^{\prime}$ region of the stem containing the recognition site of RNAase III. The dimensions of these functional parts were adopted from published $E$. coli sequences. The promoter-leader 

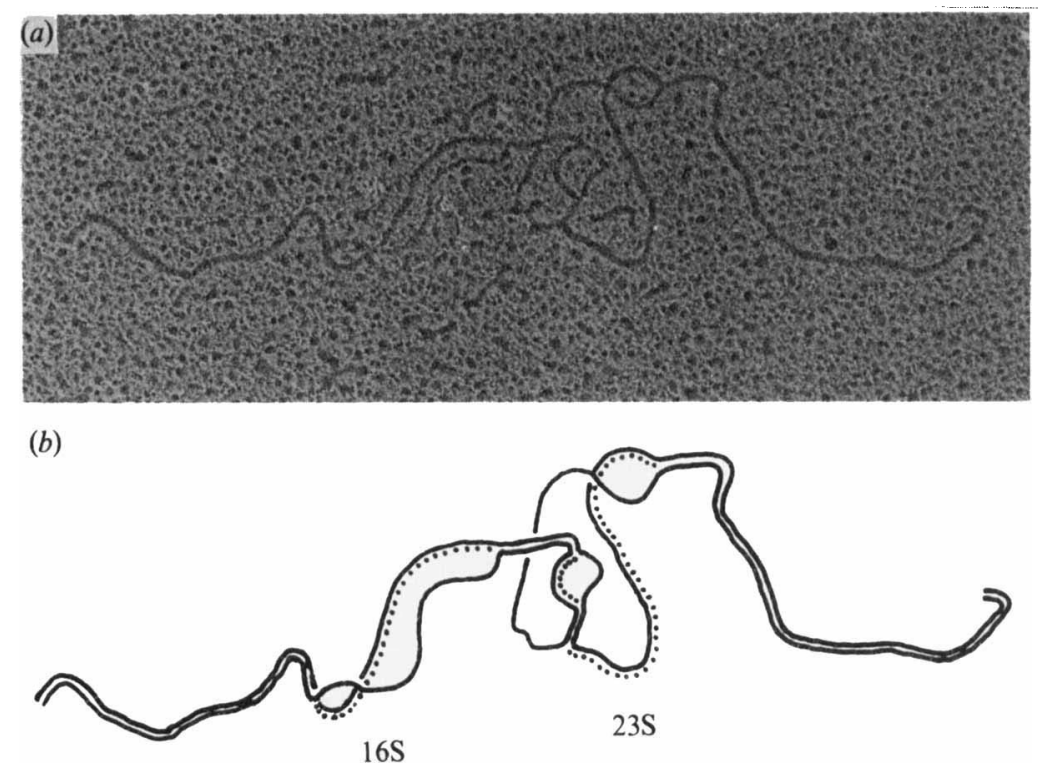

Fig. 2. R-loop analysis of $16 \mathrm{~S}$ and $23 \mathrm{~S}$ rRNA. Electron micrograph $(a)$ and schematic representation $(b)$ of the location of $16 \mathrm{~S}$ and $23 \mathrm{~S}$ rRNA genes in the BamHI insert of pPM2. DNA and RNA are indicated as solid and dashed lines, respectively.

region of the $P$. vulgaris rrn operon consists of two promoters (P1 and P2), separated by 107 bp ( $5^{\prime}$ of -10 regions). Both promoters exhibit high sequence homology with those of $E$. coli. While the -10 region of $P 1$ is identical to the homologous regions of all $E$. coli cistrons, the -10 region of $\mathrm{P} 2$ is identical to those of $r r n D$ and $r r n E$ (Young \& Steitz, 1979; de Boer et al., 1979). The - 35 regions (12 bp long according to Brosius et al., 1981 a) of both promoters are in no case identical to any of the $E$. coli counter-parts. Limiting the -35 region to the central sequences (Lamond $\&$ Travers, 1985) the homology is obvious.

\section{Expression of heterologous $16 S$ rRNA}

Plasmid copy number was determined (Fig. 4) and under exponential growth conditions it was about 8 and 10 for pPM14 and pPM2, respectively, per haploid $E$. coli genome. These numbers are of the same order of magnitude as the number of rRNA genes in the host cell, previously determined to be 7 (Kenerley et al., 1977; Kiss et al., 1977).

The transcription of functional heterologous $16 \mathrm{~S}$ rRNA can be verified by demonstrating its presence in isolated $E$. coli ribosomes. Fig. 5 shows that part of the RNAase T1 16S rRNA fingerprint of $E$. coli (pPM2) displaying oligonucleotides of pentamer size and larger. Selected spots representing large oligonucleotides of the 16S RNA of E. coli and P. vulgaris, respectively, are marked by different symbols. The extent of labelling of the oligonucleotides depends primarily upon the ratio of homologous and heterologous rRNAs in the ribosomes of transformed $E$. coli cells, but differences in the label of 5' nucleotides might also be influenced by the composition of the nucleotide sequence itself (Stackebrandt et al., 1985). A quantitative measurement of isolated oligonucleotides should therefore allow a crude estimation of the amount of $P$. vulgaris $16 \mathrm{~S}$ rRNA. Clone pPM2 was analysed for undissociated ribosomes, whereas $30 \mathrm{~S}$ subunits of clone pPM14 were isolated prior to the analyses. The portions of the heterologous 16S rRNA from both clones were in the range of $20-30 \%$ of total $16 \mathrm{~S}$ rRNA.

The finding that only about a quarter of the ribosomes contain heterologous $16 \mathrm{~S}$ rRNA contrasts with the approximately $1: 1$ ratio of $16 \mathrm{~S}$ rRNA genes. Possible explanations are as follows. (1) A sub-optimal recognition of the heterologous promoter region by DNA-dependent 
a CTTCGAAACGCTCGAAAAAC̈GGCAGTTTTAGGCTGATTGGTTGAATGi

$b$ AGTGATATCTCTCCTTTTTTGTTGGTTTTTTATACGTCTTGTTGGCGTTT

a TGCGCGGTCAGAAAATTATTTTAAATTCCंTCTTGTCAGGCCGGATAA

$b$ TGAACGAACAGAAAATTAT T T TAAAAAAACACTTGCGCTAATCCGAGATC $-35$

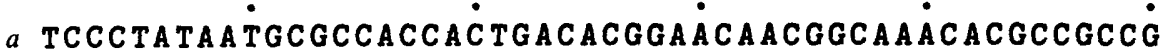

$b$ TCCCTATAATGCGCATCCASTGACCGACGATGAGCTGACAACAGCCACGA P1

a GG.TCAGCGGGGTTCTCCTGAGAACTCCGGCAGAGAAAGCAAAAATAAAT

$b$ AGGACAGCGAAG .......AGAAAA ........GAAAAAGT T TGAAAAAC

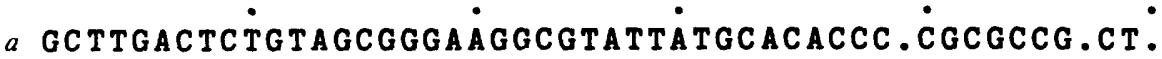
$b$ ICTIGACTCTTCAGAGGAATAACGTAATATACGC_CICCTCGCAACAACGC $-35$ P2 ..GAG ...AAAAA ..... GC

$b$ AGAAGACCGGAAACGGCAGCGAATGTTGCACTGCTCTTTAACAATTTATC Box A

$a$ AGACAATCTGTGTGGGCACTCGAAGATACGं

$b$ AGACAATCTG',GTGG, CACTCGCAGAGACG. ATATCTCTAAATATTAGA RNAase III

$a$ CGAAAAAT.....GAATACCAAGTCTCAAGAGTGAACACGTAATTCATTA

$b$ TGTATCAAGTCTTGAAGAGTGAACAACAAAAGTAAATTCATTTATGAATA

$a$.CGAAGTTT...AA.TTCTTTGAGCGTCAAAC.TTTTT

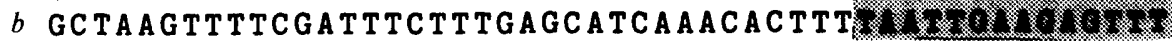

16S rRNA

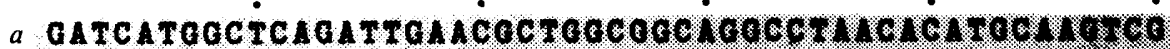

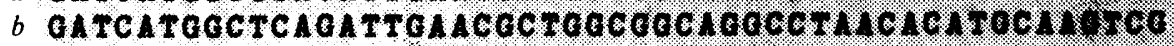

\section{a. AnCGETALigenangetr \\ b ACCGOTALCAQOAGLAAOCTR}

Fig. 3. Comparison of the primary structure of the promoter, leader region and flanking sequences of the $r n B$ cistron of $E$. coli (Brosius et al., 1981 a) (line $a$ ) and a rDNA cistron from $P$. vulgaris (pPM2) (line $b$ ). Regions of known function are marked as follows: thin line, -35 region of promoters and box A; heavy line, -10 region of promoters; boxed, RNAase III recognition site; shadowed, 5 ' region of $16 \mathrm{~S}$ rDNA gene.

RNA polymerase and/or of $16 \mathrm{~S}$ rRNA processing signals by RNAase III. These possibilities seem unlikely since, as stated above, these sites show a high degree of homology to the corresponding E. coli sequences (Brosius et al., 1981a). However, no information is available about an upstream enhancer sequence in $P$. vulgaris known to have an influence on the promoter strength of the E. coli rrn cistrons (Lamond, 1985). (2) A delayed heterologous r- 


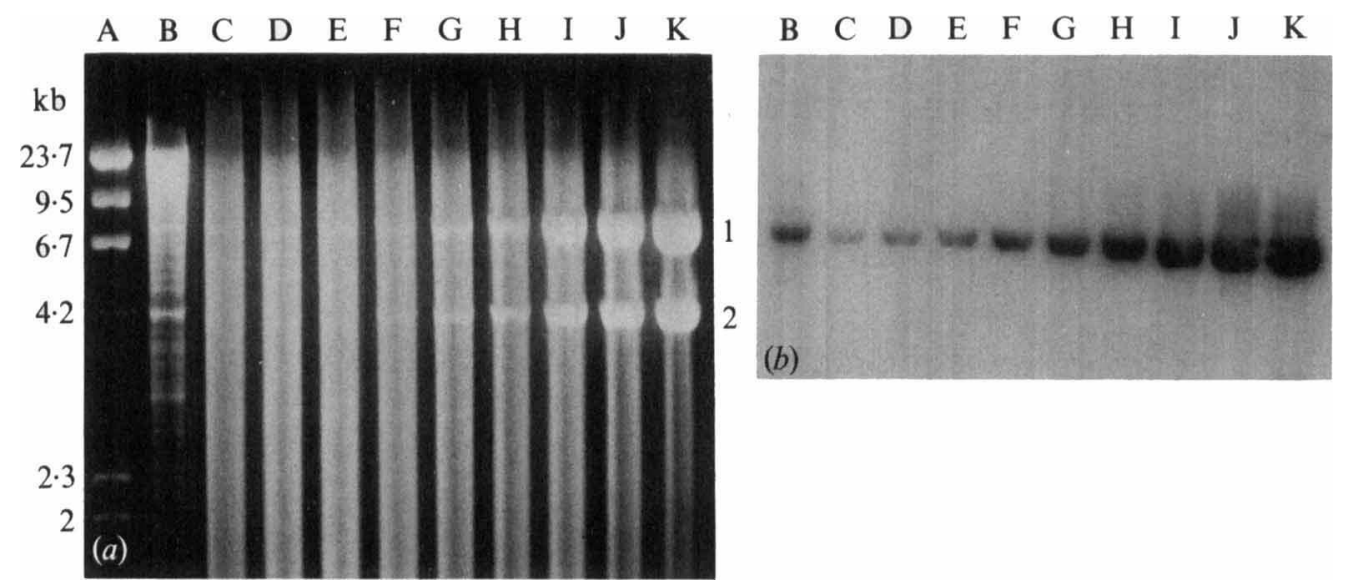

Fig. 4. Determination of plasmid copy number by agarose gel electrophoresis $(a)$ and Southern hybridization $(b)$. (a) Lane A, HindlII-digested $\lambda$ phage; lane B, $5 \mu \mathrm{g} \mathrm{BamHI-digested} \mathrm{chromosomal}$ DNA from E. coli HB101(pPM14); lane C, BamHI-digested pPM14 equivalent to the total amount of chromosomal DNA from strain HB101(pPM14) applied in lane B; lanes D-K, increasing amounts of pPM14 DNA, each lane doubling the amount of the previous lane. BamHI-digested salmon sperm DNA was added to each assay in lanes $C$ to $K$ to a total of $5 \mu \mathrm{g}$. Bands corresponding to $7.5 \mathrm{~kb}$ inserts and to $4.4 \mathrm{~kb}$ pBR322 are designated 1 and 2, respectively. (b) Autoradiogram of DNA-RNA hybrids between $5^{\prime}-\gamma_{-}{ }^{32}$ P-labelled $16 \mathrm{~S}$ rRNA from $P$. vulgaris and the BamHI digests of chromosomal and pPM14 DNA in $(a)$. The concentration of pPM14 in lane F (DNA equivalent to eight times the amount in lane B), which in signal strength is equivalent to that of lane B, gives an approximation of the plasmid copy number per haploid $E$. coli chromosome.

protein/rRNA binding, due to possible differences in the protein-binding nucleotides of the $P$. vulgaris 16S rRNA primary structure; in this case the heterologous rRNA might be more susceptible to RNAases than the homologous RNA. However, this influence seems to be less dominant since in an in vitro study on heterologous $r$-protein/rRNA interaction in bacterial ribosomes a strong heterologous binding has been reported for the Proteus vulgaris and E. coli system (Daya-Grosjean et al., 1973).

\section{Growth rate of strains carrying heterologous rrn cistrons}

While $E$. coli $\mathrm{HB} 101$, containing no plasmid, has a doubling time of $40 \mathrm{~min}$, the doubling time increased to 57 and $70 \mathrm{~min}$ for clones harbouring pPM2 and pPM14, respectively. No increase of doubling time was observed in pBR322-containing cells (39 min), while E. coli (pKK3535) had a doubling time of $45 \mathrm{~min}$. The latter two values agree with those found by Jemiolo et al., (1985). The most likely explanation for the increased doubling time is a significant influence of the additional 10 or so cistrons on the regulation of the ribosomal components, including tRNAs (Gourse et al., 1983; Gourse \& Nomura, 1984; Jinks-Robertson et al., 1983; Siehnel \& Morgan, 1985). As discussed by Gourse et al. (1982), reduced functional efficiency of ribosomal subunits or a lowered fidelity of translation may also be responsible for the prolonged generation times.

\section{Concluding remarks}

The system introduced here is appropriate as a starting point for future attempts to establish a single copy of heterologous rDNA cistron in the $E$. coli genome. This, in the long run, would enable us to answer questions about the stability of foreign rRNA cistrons; about recombination events (Brosius et al., 1981a) and accompanying problems concerning the maintenance of almost perfect uniformity of rDNA cistron primary structures within a single strain; and about the effects of the heterologous system on the mutation rate of the 16S rDNA primary structure of 


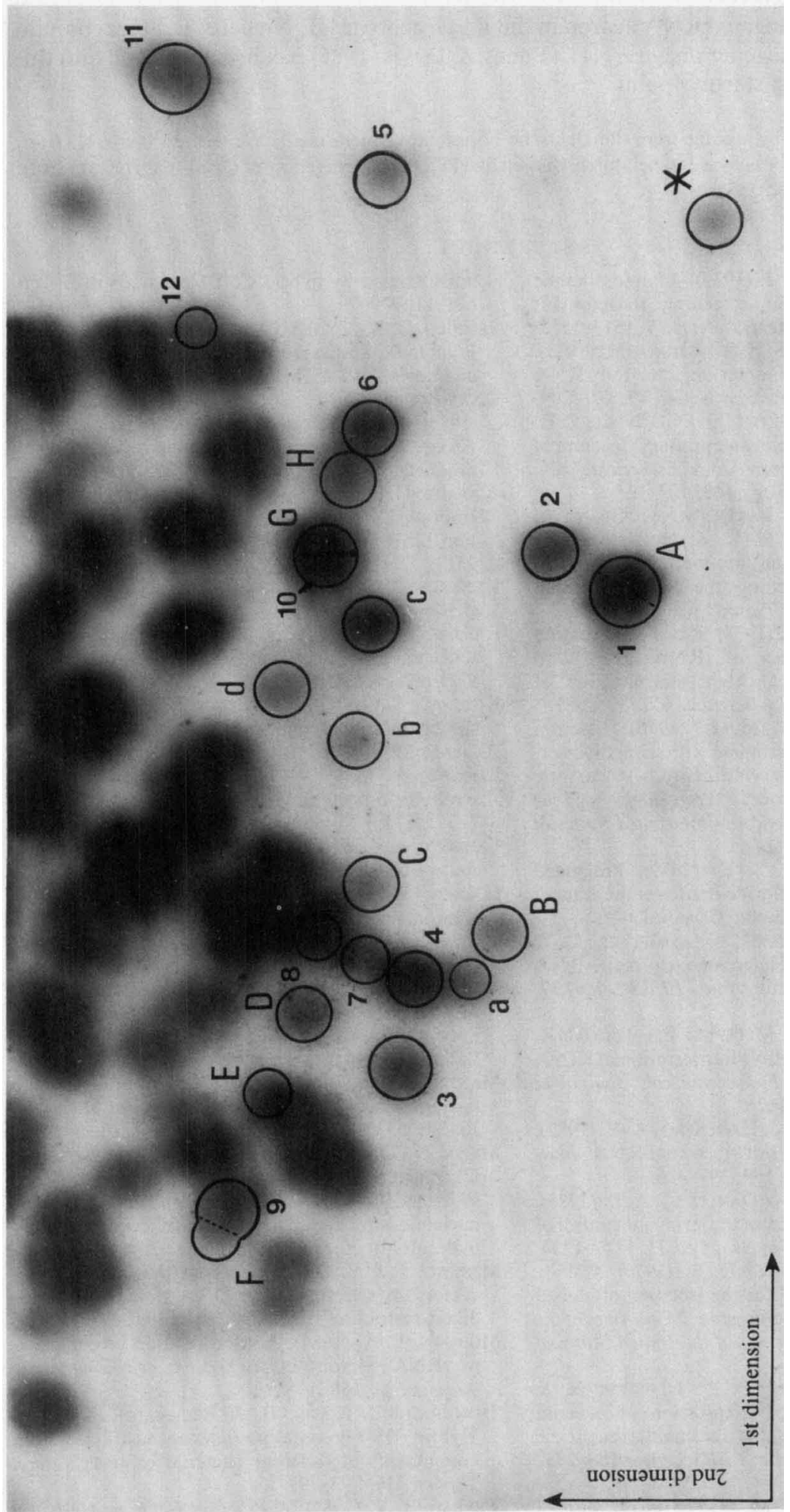

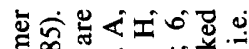

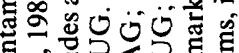

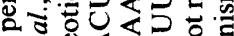

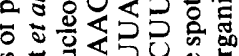

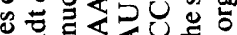

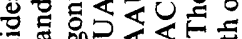
응

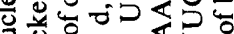

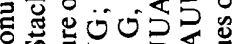
onc

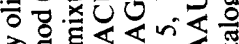
줄 0 过记 于े

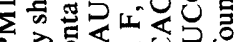
. 00 0 年 ङ 山 政行

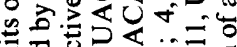
可

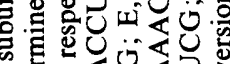

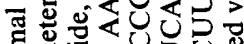

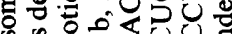
范

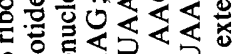

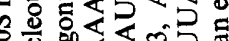
के E 릉ㅁำ 品 产记 递品之记

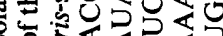
娄

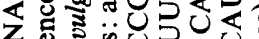

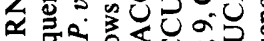

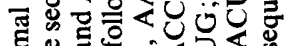
等

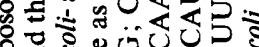

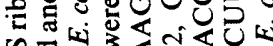
足.

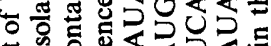

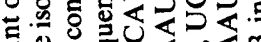

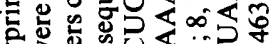
品

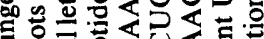
E 记

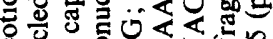

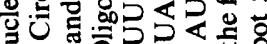
में

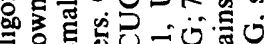
응 F

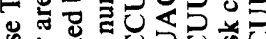
论

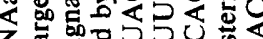

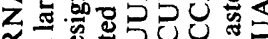

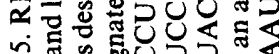

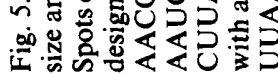


the transformed P. vulgaris cistron compared with those of the donor organism. The successful integration of a heterologous rRNA cistron in the E. coli genome $(\mathrm{H}$. Niebel \& E. Stackebrandt, unpublished) using lysogenic phage $\lambda$ gt11 (Young \& Davis, 1985) has been achieved and this represents a promising starting point.

This work was supported by a grant from the Deutsche Forschungsgemeinschaft. We wish to thank K. Apel, Insitut für Botanik, Kiel, for advice and helpful discussion and H. Noller, University of California at Santa Cruz, for providing us with pKK3535.

\section{REFERENCES}

BiRnBoim, H. C. \& Doly, J. (1979). A rapid alkaline extraction procedure for screening recombinant plasmid DNA. Nucleic Acids Research 7, 1513-1523.

DE Boer, H. A., Gilbert, S. F. \& Nomura, M. (1979). DNA sequences of promoter regions for rRNA operons rrnE and $r n A$ in E. coli. Cell 17, 201-209.

Brosius, J., Dull, T., Sleeter, D. D. \& Noller, H. (1981 a). Gene organization and primary structure of a ribosomal RNA operon from Escherichia coli. Journal of Molecular Biology 148, 107-127.

Brosius, J., Ullrich, A., Raker, M. A., Gray, A., Dull, T. J., Gutell, R. R. \& Noller, H. F. $(1981 b)$. Construction and fine mapping of recombinant plasmids containing the $r n n B$ ribosomal RNA operon of E. coli. Plasmid 6, 112-118.

CASEY, J. \& DAvidSON, N. (1977). Rates of formation and thermal stabilities of RNA:DNA and DNA:DNA duplexes at high concentration of formamide. Nucleic Acids Research 4, 1539-1552.

Cech, T. R. \& Pardue, M. L. (1976). Electron microscopy of DNA crosslinked with trimethylpsoralen: test of the secondary structure of eucaryotic inverted repeat sequences. Proceedings of the National Academy of Sciences of the United States of America 73, 2644-2648.

DAgert, M. \& Ehrlich, S. D. (1979). Prolonged incubation in calcium chloride improves the competence of Escherichia coli cells. Gene 6, 23-28.

Daya-Grosjean, L., Greisser, M., Stöffler, G. \& GARRET, R. A. (1973). Heterologous protein-RNA interactions in bacterial ribosomes. FEBS Letters 37, 17-20.

GOURSE, R. L. \& NoMURA, M. (1984). Level of rRNA, not tRNA, synthesis controls transcription of rRNA and tRNA operons in Escherichia coli. Journal of Bacteriology 160, 1022-1026.

Gourse, R. L., Stark, M. \& DAHLbERG, A. E. (1982). Site-directed mutagenesis of ribosomal RNA. Journal of Molecular Biology 159, 397-416.

Gourse, R. L., StARK, M. \& DAHLberg, A. E. (1983). Regions of DNA involved in the stringent control of plasmid-encoded rRNA in vivo. Cell 32, 1347-1354.

GRUNSTEIN, M. \& HogNess, D. S. (1975). Colony hybridization: a method for the isolation of cloned DNAs that contain a specific gene. Proceedings of the National Academy of Sciences of the United States of America 72, 3961-3965.

Hartmann, R. K., Henze, P. P., Ulbrich, N. \& ERDMANN, V. A. (1985). Expression of plasmid encoded Escherichia coli 5S ribosomal ribonucleic acid in Pseudomonas putida. FEBS Letters 188, 295301.

IKEMURA, T. \& NomURA, M. (1977). Expression of spacer tRNA genes in ribosomal RNA transcription units carried by hybrid ColE1 plasmids in E. coli. Cell 11, 779-793.

Jemiolo, D. K., Zwieb, C. \& Dahlberg, A. E. (1985). Point mutations in the $3^{\prime}$ minor domain of 16 S rRNA of E. coli. Nucleic Acids Research 13, 8631-8643.

Jinks-Robertson, S., Gourse, R. L. \& Nomura, M. (1983). Expression of rRNA and tRNA genes in Escherichia coli: evidence for feedback regulation by products of rRNA operons. Cell 33, 865-876.

KABACK, D. B., ANGERER, L. \& DAvidson, N. (1979). Improved methods for the formation and stabilization of R-loops. Nucleic Acids Research 6, 24992517.

Kenerley, M. E., Morgan, E., Post, L., Lindahl, L. \& NomURA, M. (1977). Characterization of hybrid plasmids carrying individual ribosomal ribonucleic acid transcription units of Escherichia coli. Journal of Bacteriology 132, 931-949.

Kiss, A., Sain, B. \& Venitianer, P. (1977). The number of rRNA genes in Escherichia coli. FEBS Letters 79, 77-79.

LAMOND, A. I. (1985). The control of stable RNA synthesis in bacteria. Trends in Biochemical Sciences 7, 271-274

Lamond, A. I. \& Travers, A. A. (1985). Stringent control of bacterial transcription. Cell 41, 6-8.

LOENEN, W. \& BLATTNER, F. R. (1983). Lambda Charon vectors (Charon 32, 33, 34 and 35) adapted for DNA cloning in recombination-deficient hosts. Gene 26, 171-179.

Maniatis, T., Fritsch, E. F. \& Sambrook, J. (1982). Molecular Cloning, a Laboratory Manual. Cold Spring Harbor, NY: Cold Spring Harbor Laboratory.

MANDEL, M. \& Higa, A. (1970). Calcium-dependent bacteriophage DNA infection. Journal of Molecular Biology 53, 159-162.

MeIER, N., Göringer, H. U., Kleuvers, B., Scheibe, U., Eberle, J., Szymkowiax C., Zacharias, M. \& WAGNER, R. (1986). The importance of individual nucleotides for the structure and function of rRNA molecules in E. coli. FEBS Letters 204, 89-95.

Messing, J. \& VieIRA, J. (1982). A new pair of M13 vectors for selecting either DNA strand of doubledigest restriction fragments. Gene 19, 269-276.

MoRGaN, E. A. (1986). Antitermination mechanisms in rRNA operons of Escherichia coli. Journal of Bacteriology 168, 1-5.

Nomura, M., Traub, P. \& Bechmann B. (1968). Hybrid 30 S ribosomal particles reconstructed from components of different bacterial origins. Nature, London 219, 793-799.

Perbal, B. V. (1984). A Practical Guide to Molecular Cloning. New York \& Toronto: John Wiley. 
REED, K. C. \& MANN, D. A. (1985). Rapid transfer of DNA from agarose gels to nylon membranes. Nucleic Acids Research 13, 7207-7221.

SANGer, F., Nicklen, S. \& Coulson, A. R. (1977). DNA sequencing with chain-terminating inhibitors. Proceedings of the National Academy of Sciences of the United States of America 74, 5463-5467.

SieHNEL, R. J. \& Morgan, E. A. (1985). Unbalanced rRNA gene dosage and its effects on rRNA and ribosomal-protein synthesis. Journal of Bacteriology 163, 476-486.

SkinNer, R. H., STARK, M. \& Dahlberg, A. E. (1985). Mutations within the 23S rRNA coding sequence of $E$. coli which block ribosome assembly. $E M B O$ Journal 4, i605-1608.

SOUTHERN, E. (1975). Detection of specific sequences among DNA fragments separated by gell electrophoresis. Journal of Molecular Biology 98, 503-517.

STACKEBRANDT, E., LUDWIG, W. \& FoX, G. E. (1985). 16S ribosomal RNA oligonucleotide cataloguing. Methods in Microbiology 18, 75-107.

Stark, M., Gourse, R. L. \& DaHLberG, A. E. (1982).
Site-directed mutagenesis of ribosomal RNA. Journal of Molecular Biology 159, 417-439.

Traub, P., Mizushima, S., Lowry, C. V. \& Nomura, M. (1971). Reconstruction of ribosomes from subribosomal components. Methods in Enzymology 22C, 391-407.

WOOLFORD, J. L. \& Rosebash, N. (1979). The use of Rlooping for structural gene identification and mRNA-purification. Nucleic Acids Research 6, 24832497.

Young, R. A. \& Steitz, J. A. (1979). Tandem promoters direct $E$. coli ribosomal RNA synthesis. Cell 17, 225-234.

Young, R. A. \& DAvis, R. W. (1985). Immunoscreening lambda gtll recombinant DNA expression libraries. In Genetic Engineering, vol 7, pp. 29-41. Edited by J. Setlow \& A. Hollaender, London: Plenum Press.

ZABLEN, L. \& WoESE, C. R. (1975). Procaryote phylogeny. IV. Concerning the phylogenetic status of a photosynthetic bacterium. Journal of Molecular Evolution 5, 25-34. 